\title{
APPROACH TO CLUSTERING COSTS AND LOSSES INCURRED AS A RESULT OF GAS NETWORK FAILURE
}

\begin{abstract}
The availability of the gas supply system safety concerns the crucial issue in gas infrastructure operation and management. In recent years, the observed development of gas supply system does not protect against the failure occurrence of the gas network. Gas network requires proper analysis of its functioning, as it forms a complex system. Gas companies are responsible for supplying gas to consumers in reliable and safe way. In the paper the approach to failure cost and losses assessment with implementation of clustering analysis was presented. Such comparison can be helpful in costs assessment in different distribution gas systems. The analysis, was based on the operational data obtained from the gas companies.
\end{abstract}

Keywords: gas network functioning, gas network, gas losses, gas network failure

\section{Introduction}

Regardless of the type and purpose of the technical system costs associated with failures constitute an important position in the overall cost of system operation. Generally, the cost of failure removal consists of the employees salary, the materials used to the failure removal and the possible consequences of the failure [8]. Due to the nature of the transmitted medium, the failures of natural gas distribution networks can cause relatively high costs, mainly due to the consequences of the potential accidents. In the case of gas networks, even a seemingly harmless failure can cause substantial material or human losses [6].

To determine the total cost of network failure removal we must take into account many factors: the type of pipeline, the location of the failure (built-up area or open space) if there is a gas leak, duration of the outage and finally the consequences caused by network failure. The most dangerous is damage of the gas lines that are located in enclosed areas (e.g. buildings, frozen land) because in such a place the incoming gas quickly reaches the explosive concentration. Gas explosion can cause major damage, which in turn contributes to the cost of

\footnotetext{
${ }^{1}$ Marek Urbanik, Politechnika Rzeszowska, al. Powstańców Warszawy 6, 35-959 Rzeszów,
} tel.1786514408,d314@stud.prz.edu.pl 
failure. The cost of eliminating the failure of the gas network is not always covered by the gas company $[1,10]$. Where the perpetrator is known, then the costs associated with failure removal are transferred to the perpetrator. If the gas installation inside the building is damaged, the building owner will be responsible for removing the failure.

To decrease the consequences of failure in gas supply subsystem active procedures from the design stage to gas infrastructure operation should be implemented $[9,11]$.

The management of the gas network should perform the detailed analysis of failures and cost associated with it. Therefore the objective of this work is to characterize the preliminary analysis of associated costs and losses occurred as a result of gas network failure. In the assessment of losses associated with failure data from exploitation of real gas network was used.

\section{The use of multidimensional comparative analysis to assess the costs and losses incurred as a result of pipeline failure}

The term of cluster analysis was first used by Robert Tryon in 1939, the aim of the method is to associate data of similar properties into a cluster creating taxonomies.

Clustering is a data analysis tool that sorts different objects into clusters so that the similarity of two objects belonging to one group is the maximum, while similarity of objects outside this cluster is minimal. Through implementation of cluster analysis it is possible to find dependence between objects. Calculating distances between clusters through agglomeration hierarchical grouping methods were collected in works $[3,4]$.

To determine the distance between clusters the Ward's method was applied, which is based on the loss of information that occurs during clustering [12]. The criterion for clustering is the sum of squared deviations of each object from the centroid of a cluster to which it belongs. The Ward's method is very often used because of the efficiency of its results, despite the fact that as a result of its use are created the clusters of a very small distance. The next step that has been taken in assessing the cost of failure of gas pipelines is to construct distance matrices and then the use of the cluster agglomeration method.

The methodology presented in [2] was used to determine the distance between points belonging to two different clusters (subsets). In order to obtain an optimum number of clusters, the critical distance was determined as the sum of the arithmetic mean and the standard deviation for the minimum values in the individual rows of the distance matrix [7]. The next step in the analysis was the individual classification of the data, which included the following parameters: slit area, absolute pressure of gas, amount of gas losses, the duration of the failure, cost of gas losses, cost of failure removal. 


\section{Results and discussion}

On the basis of the grouping performed by the Ward's method the course of agglomeration was obtained. Information about the distance bonds in the course of agglomeration is presented in Figure 1.

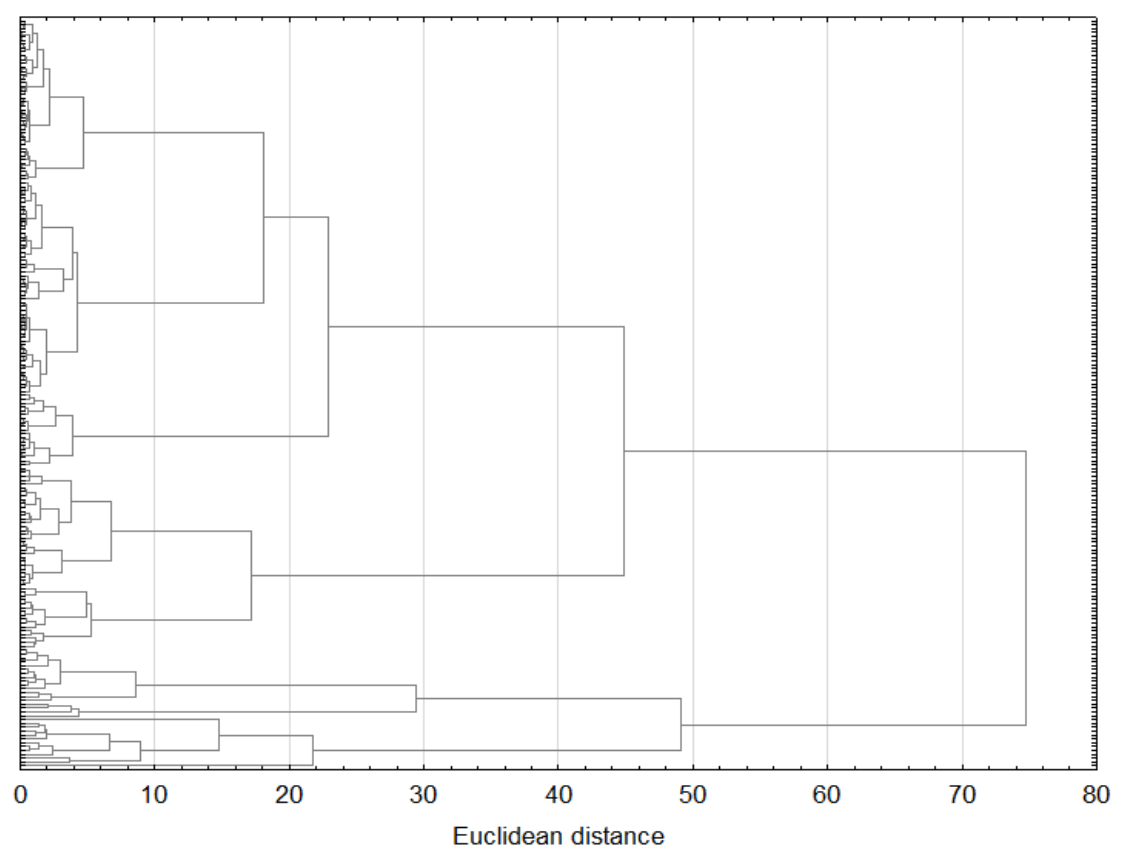

Fig. 1. Dendrogram tree of cluster agglomeration

Rys. 1. Dendrogram drzewa aglomeracji skupień

In order to show the differentiation of individual clusters, the k-means method is used [5]. The applied method is an iteration method, which allows for obtaining as different clusters as possible. Such approach is possible by moving objects from one cluster to the other. As a result of the agglomeration, variation within the cluster and between clusters are optimized. Similarity within cluster should be the highest and separate clusters should maximally differ from each other. It should be noticed that non-hierarchical method does not guarantee the single solutions with regard to the initial conditions.

Obtaining clusters that maximally differ from each other makes it possible to obtain clear results, which is important when grouping a large number of cases in distinguished analysis.

The performed analysis can be described in the following steps: firstly determining for each cluster the centre of gravity, then assigning each element to the nearest centre of gravity. After repeating this process the new centroid is 
formed until the new assignment occurs. The determined clusters are characterized by small intra-group variance and large intergroup variance. This is confirmed by the value of statistics showing a statistically significant classification.

In the Figure 2 number of individual clusters occurred after the process of cluster agglomeration is shown.

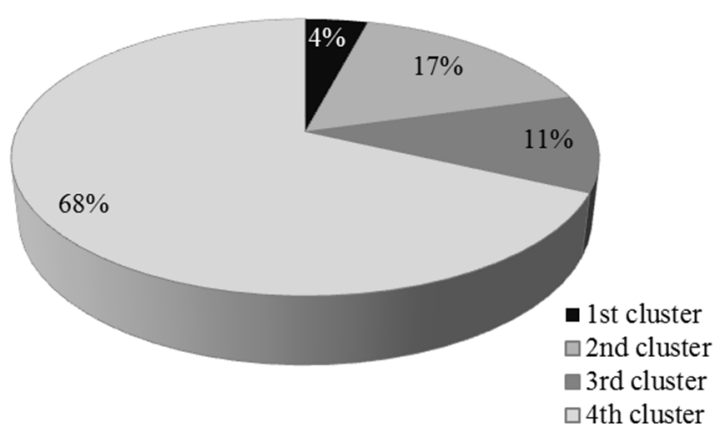

Fig. 2. Number of individual clusters occurred after process of cluster agglomeration

Rys. 2. Liczebność poszczególnych skupień powstałych w wyniku przebiegu aglomeracji

Figure 3 shows the average characteristics of the individual clusters obtained by clustering using the k-means method.

Taking into account the aggregated costs, individual clusters can be characterized as follows. The first cluster (4\% of all cases) is characterized by very high costs for gas losses and high costs of failure removal. The detailed analysis of the first cluster indicated that failures with similar reasons of occurrence are characterized by the smaller silt area on the pipes made of PE (on average $5,84 \mathrm{~cm}^{2}$ ), than this one made from steel. On the slit area size also have influence the absolute pressure of gas (on average $336 \mathrm{kPa}$ ) and time of gas leaks during failure. These two parameters are also bigger in the distinguished cluster. The second cluster (17\% of all cases) is formed by the failures of the lowest cost of gas losses and very high cost of failure removal. The second cluster was dominated by failures of older pipes made of steel and are characterized by long time of failure removal, what resulted in higher cost of failure removal. For such grouping the elements have influence the higher cost of materials and work machines, than in other clusters, at the same time with no significant costs of gas losses. The lowest costs incurred during failure occurred in the third cluster (11\% of all cases) and the average in the fourth cluster, in which there are low cost of the gas losses and the average costs of failure removal. The fourth cluster is formed by the largest number of distinguished failures (68\% of all cases) and the smallest variation within the group, what was demonstrated by a standard deviation in comparison to other clusters. 
a)

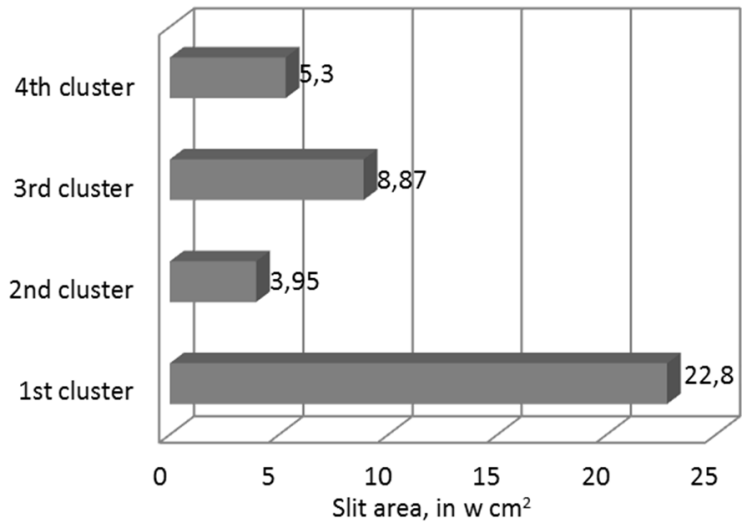

b)

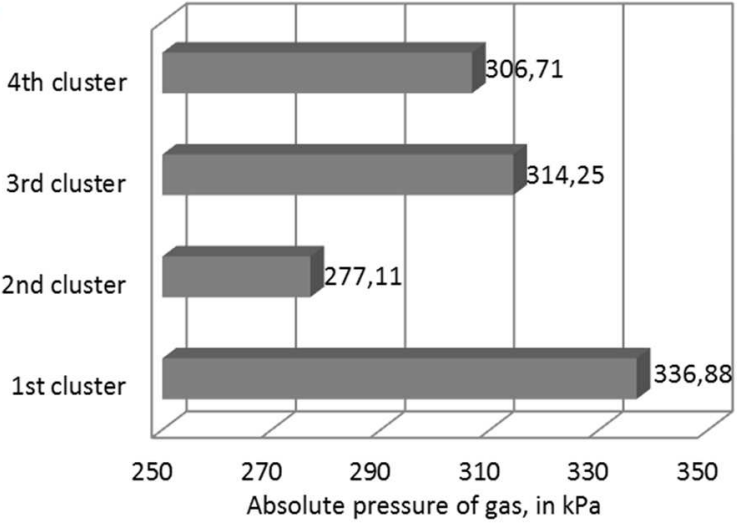

c)

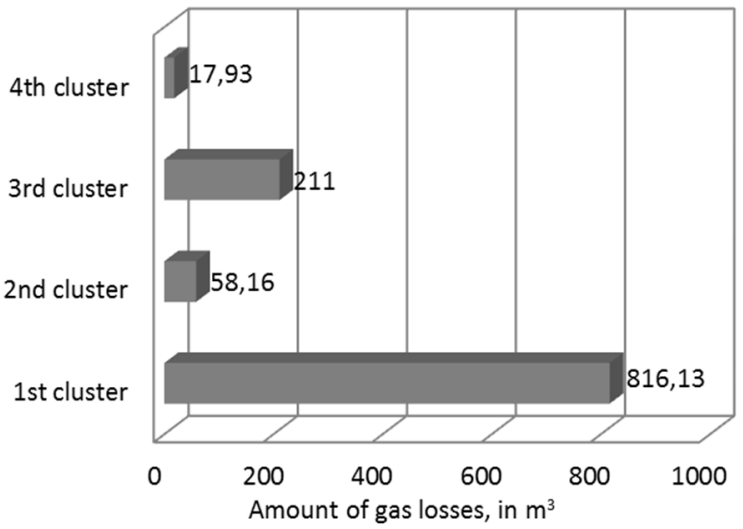

Fig. 3. Average characteristics of failure and the costs associated with their removal using the method of k-means: a) slit area, b) absolute pressure of gas, c) amount of gas losses, d) the duration of the failure, e) cost of gas losses, f) cost of failure removal

Rys. 3. Charakterystyka awarii oraz średnich kosztów związanych z ich usuwaniem z zastosowaniem metody k-średnich: a) powierzchnia szczeliny, b) ciśnienie absolutne gazu, c) ilość utraconego gazu, d) czas trwania awarii, w h, e) koszt utraconego gazu, f) koszty usunięcia awarii 
d)

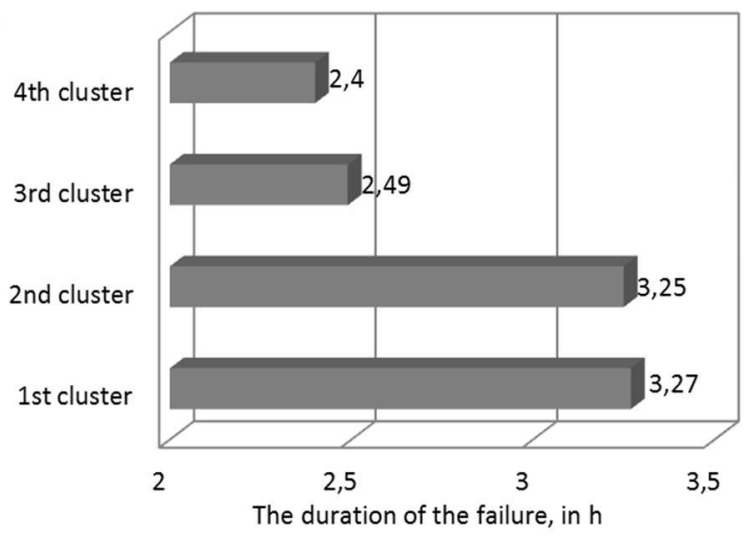

e)

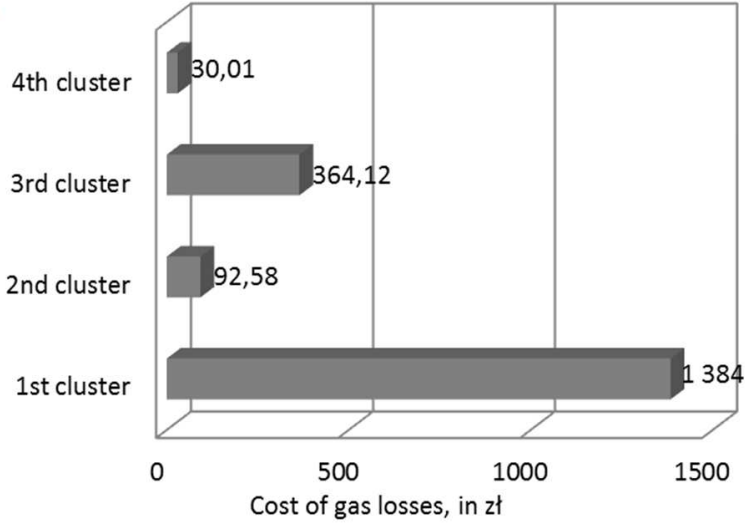

f)

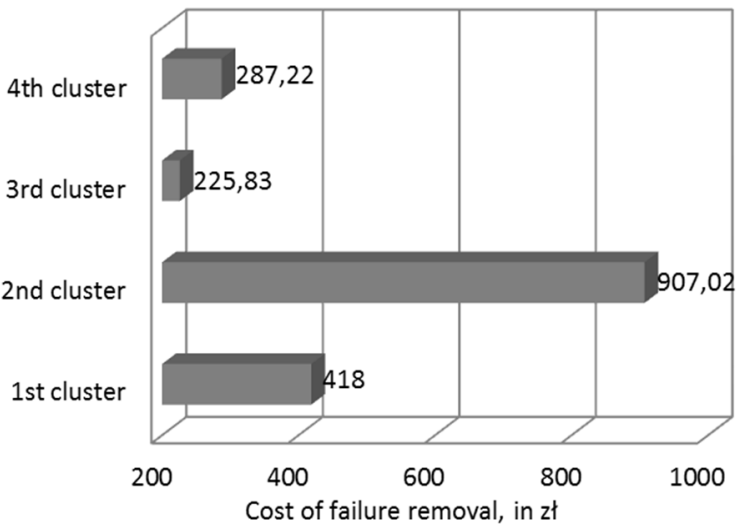

Fig. 3 (cont.). Average characteristics of failure and the costs associated with their removal using the method of k-means: a) slit area, b) absolute pressure of gas, c) amount of gas losses, d) the duration of the failure, e) cost of gas losses, f) cost of failure removal

Rys. 3 (cd.). Charakterystyka awarii oraz średnich kosztów związanych z ich usuwaniem z zastosowaniem metody k-średnich: a) powierzchnia szczeliny, b) ciśnienie absolutne gazu, c) ilość utraconego gazu, d) czas trwania awarii, w h, e) koszt utraconego gazu, f) koszty usunięcia awarii 


\section{Conclusion}

Safe and reliable gas supply considerably is determined by failure occurrence. Assets of gas companies are largely formed by gas network, due to this fact it is crucial to decrease costs of gas infrastructure functioning together with supplying gas with appropriate parameters.

Therefore, the management of the gas supply system should be conducted in such way, as to include the detailed analysis of failures, what will ensure the reduction of losses incurred as a result of failure to a minimum.

The presented approach can be used to describe the cost and losses being a result of failure of gas network. It can provide information for comparison assessment between gas supply systems in regards to the cost and losses of failure occurrence on gas pipes.

The further research will indicate the dependence analysis between the failure parameters influencing the cost associated with the failure removal.

\section{Literature}

[1] Dieckhoener C., Lochner S., Lindenberger D.: Simulating the Effects of European Natural Gas Infrastructure Developments, Oil Gas-European Magazine, 36(4) 2010, pp. 174-185.

[2] Hellwig Z.: Zarys ekonometrii, PWE, Warszawa 1973.

[3] Lance G.N., Williams W.T.: A general theory of classificatory sorting strategies: II. Clustering systems, The Computer Journal, 10(3)1967, pp. 271-277.

[4] Lance G.N., Williams W.T.: A general theory of classificatory sorting strategies, I. Hierarchical systems, The Computer Journal, 9(4)1967, pp. 373-380.

[5] MacQueen, J. Some methods for classification and analysis of multivariate observations. Proceedings of the Fifth Berkeley Symposium on Mathematical Statistics and Probability, Volume 1: Statistics, 281-297, University of California Press, Berkeley, Calif., 1967.

[6] Majid, Z.A., Mohsin, R., Yaacob, Z., Hassan, Z.: Failure analysis of natural gas pipes, (2010) Engineering Failure Analysis, 17 (4), pp. 818-837.

[7] Marek T.: Analiza skupień w badaniach empirycznych. PWN, Warszawa 1989.

[8] Rak J.: Metoda planowania remontów sieci wodociągowej na przykładzie miasta Krosna, Czasopismo Inżynierii Lądowej, Środowiska i Architektury - Journal of Civil Engineering, Environment and Architecture, JCEEA, t. XXXI, z. 61 (1/14), 2014, s. 225-232. DOI:10.7862/rb.2014.15.

[9] Shalaby, H.M., Riad, W.T., Alhazza, A.A., Behbehani, M.H.: Failure analysis of fuel supply pipeline, Engineering Failure Analysis, 13 (5)2006, pp. 789-796.

[10] Urbanik M., Tchórzewska-Cieślak B.: Ecological aspects of the natural gas use, Czasopismo Inżynierii Lądowej, Środowiska i Architektury - Journal of Civil Engineering, Environment and Architecture, JCEEA, t. XXXII, z. 62(1/15), s. 409-417. DOI: $10.7862 / \mathrm{rb} .2015 .29$. 
[11] Urbanik M., Tchórzewska-Cieślak B.: Podstawy analizy niezawodności funkcjonowania instalacji wykorzystujących gaz ziemny, Czasopismo Inżynierii Lądowej, Środowiska i Architektury - Journal of Civil Engineering, Environment and Architecture. JCEEA, t. XXXII, z. 62 (1/15), s. 419-431. DOI: 10.7862/rb.2015.30.

[12] Ward J. H.: Hierarchical grouping to optimize an objective function, Journal of the American Statistical Association, 58(3)1963, pp. 236-244.

\section{ZASTOSOWANIE METODY GRUPOWANIA KOSZTÓW ORAZ STRAT PONOSZONYCH W WYNIKU AWARII}

\section{Streszczenie}

Bezpieczeństwo dostaw gazu ma decydujące znaczenie w zarządzaniu i eksploatacji infrastruktury gazowej. W ostatnich latach obserwowany rozwój systemu zaopatrzenia w gaz nie chroni przed wystąpieniem awarii na sieci gazowej. Sieć gazowa wymaga prawidłowej analizy jej funkcjonowania, ponieważ stanowi złożony system. Zakłady gazownicze są odpowiedzialne za dostarczanie konsumentom gazu w sposób niezawodny i bezpieczny. W artykule przedstawiono podejście do oceny kosztów i strat przy zastosowaniu analizy skupień. Takie porównanie może być pomocne w ocenie kosztów w różnych systemach dystrybucji gazu. Analiza została oparta na danych eksploatacyjnych uzyskanych od zakładów gazowniczych.

Słowa kluczowe: funkcjonowanie sieci gazowej, sieć gazowa, straty gazu, awaria sieci gazowej

Przestano do redakcji: 15.10.2016 r.

Przyjęto do druku: 31.03.2017 r. 